\title{
Correction to: Organic residues as adsorbent for the removal of ciprofloxacin from aqueous solution
}

\section{María Eulalia Peñafiel ${ }^{1}$ - Eulalia Vanegas ${ }^{1} \cdot$ Daniel Bermejo $^{1} \cdot$ José María Matesanz $^{2}$. María P. Ormad ${ }^{2}$}

Published online: 5 September 2019

(C) Springer Nature Switzerland AG 2019

\section{Correction to: Hyperfine Interactions (2019) 240:71 https://doi.org/10.1007/s10751-019-1612-9}

Due to technical constraints this article was published in volume 240:1 with erroneous article citation ID number 1 whereas this should have been $\mathbf{7 1}$ which is corrected as such. Springer Nature sincerely apologizes towards the author(s) for the inconvenience caused.

Publisher's note Springer Nature remains neutral with regard to jurisdictional claims in published maps and institutional affiliations.

This article is part of the Topical Collection on Proceedings of the 16th Latin American Conference on the Applications of the Mössbauer Effect (LACAME 2018), 18-23 November 2018, Santiago de Chile, Chile Edited by Carmen Pizarro Arriagada

The online version of the original article can be found at https://doi.org/10.1007/s10751-019-1612-9

María Eulalia Peñafiel

maria.penafiel@ucuenca.edu.ec

Eulalia Vanegas

eulalia.vanegas@ucuenca.edu.ec

Daniel Bermejo

daniel.bermejo0101@ucuenca.edu.ec

José María Matesanz

matesanz@unizar.es

María P. Ormad

mpormad@unizar.es

Extended author information available on the last page of the article 


\section{Affiliations}

María Eulalia Peñafiel ${ }^{1} \cdot$ Eulalia Vanegas $^{1} \cdot$ Daniel Bermejo $^{1} \cdot$ José María Matesanz $^{2}$. María P. Ormad ${ }^{2}$

1 Center for Environmental Studies, Department of Applied Chemistry and Production Systems, Faculty of Chemical Sciences, University of Cuenca, Av 12 de Abril y Agustín Cueva, Cuenca, Ecuador

2 School of Engineering and Architecture/ Institute of Environmental Sciences, Spain, University of Zaragoza, Calle de Pedro Cerbuna, 12, 50009 Zaragoza, Spain 